\title{
Empirical Evidence of Capital Mobility in the EU New Member States
}

\author{
Ines Kersan Škabić*
}

\begin{abstract}
This research is focused on the analysis of capital mobility indicators in the EU new member states as capital market union is one of the newest initiative in the EU. We found the most integrated countries are Hungary, the Czech R., Croatia and Estonia. Econometric analysis emphasized the main determinants of capital account openness and of FDI inward stock. The analysis indicates that the level of development, intra-EU trade and FDI inward stock have a positive impact on capital account openness (mobility), while inflation has a negative influence. The GDP per capita, intra- EU trade and capital account openness have positive impact on FDI inward stock while inflation and gross fixed capital formation have negative influence. Unexpectedly, fiscal variables and interest rates do not have a significant impact on capital openness. The results show that there is room for improvement in all countries that would enable more favorable access to capital.
\end{abstract}

Keywords: capital mobility; capital market union; EU; FDI

JEL Classification: F21, F43

\section{Introduction}

Nowadays, capital market integration is actualized through the idea of forming a capital markets union (European Commission, 2015a). Capital mobility (as a part of financial integration) is a crucial arm to direct investments to the most profitable projects anywhere in the EU according to the investor's expectation on profitability. The common market (in EU) is based on the assumption of free movement of goods, services, capital and people and it means that there are no formal barriers to making investments anywhere in the EU. Financial services were supposed to be

\footnotetext{
* Ines Kersan Škabić is at Juraj Dobrila University of Pula, Faculty of Economics and Tourism "Dr. Mijo Mirkovic", Pula, Croatia.
} 
liberalised as part of the 1992 Single Market project. The international capital mobility increased during the 1990s and 2000s and an additional push factor was the EU enlargement to the countries of Central and East Europe, but there is still uneven development of capital market integration in the EU. A well-functioning economy needs a financial system that moves funds from people who save to people who have productive investment opportunities. In other words, a sound financial system acts as a conduit for sustainable economic growth. Economic theory and empirical findings suggest that the integration and development of financial markets are likely to contribute to economic growth by removing frictions and barriers to exchange, and by allocating capital more efficiently. One part of the story concerns formal procedure for making investments abroad and the second part is the confidence on the home country (institutions, market efficiency, etc.).

Capital mobility is one aspect of financial market integration that, as broad concept, includes the integration of money, bond, credit, and equity markets and it is very difficult to measure the level of financial integration of all (financial) markets as it requires dealing with different variables and methodologies. However, there is the possibility of choosing one particular market and measuring its level of integration in a particular country (or group of countries) or including different measures (relevant to various aspects of market integration) for all financial markets in order to construct a general perspective on the achievements and setbacks of the process (Pungules$\mathrm{cu}, 2004)$. Countries may share a common legal and regulatory framework, but still identical assets may command different returns. Beyond legal barriers, there might be economic barriers, for instance situations of asymmetric information that induce investors to evaluate differently assets that are otherwise identical.

The existing literature generally concludes that financial integration within the euro area is apparent and enlarging. However, the evidence on financial integration between the groups of old and new EU member states emphasize there are many differences between these two groups of countries. Nevertheless, the European Commission (2009) concludes that integration between the old and new parts of the EU has been advancing rapidly, albeit in a different form than that among the euro area members. World financial crisis significantly influence on the process of European financial integration because other hidden economic problems became visible and they degrades the achievements of the single market (Stavarek et al., 2011).

In this paper we have chosen to provide in-depth analysis of capital market integration in the new EU member states (the countries of Central and East Europe, CEE). Capital mobility is measured by two indicators: kaopen index and FDI inward stock (as the main channel of capital mobility is through FDI). The novelty of this paper is the complex approach to the topic where we will analyze the two sides of capital integration: statistical data of different aspects of capital markets and econometric analysis to find out the main determinants of capital mobility. The motivation comes from the fact that de jure liberalization does not mean that integration is real- 
ized in practice (de facto integration). This difference has somehow been overlooked in the literature, perhaps because economists are focused on measuring the degree of financial integration in Europe, and political scientists' research is usually limited to the European regulatory convergence and supranational legislation (Grossman and Leblond, 2008).

The paper consists of five chapters. A literature review concerning the measurement of capital market integration is provided in the second chapter. The third chapter includes a comparison of statistical data of the key variables of capital market integration. The fourth chapter is research of the main determinants of capital openness followed by the critical assessment and conclusion.

\section{Literature Review}

In devising the measures, we were inspired by the existing literature on measuring capital market (financial) integration. Financial integration is important for the effective transmission mechanism of monetary policy in the Eurozone. According to Baele et al. (2004) a financial market is fully integrated when all participants on the market face a single set of rules when they decide to deal with those financial instruments and/or services; have equal access to the above-mentioned set of financial instruments and/or services, and are treated equally when they are active in the market.

Primarily it is necessary to make a distinction between financial and capital market integration. The literature, for example, Oxelheim (1990) or Guha et al. (2004), distinguishes between total, direct and indirect financial integration. The total financial integration thus embraces direct and indirect integration and it means that expected real interest rates are the same on the markets concerned. Where total financial integration is not perfect, the reason may be imperfect direct and/or indirect financial integration. Kalemli-Ozcan and Manganelli (2008) showed that given the variety of asset classes traded, the measurement of financial integration is not straightforward. Direct financial integration, which is also called capital market integration, is expressed in deviations from the law of one price for financial securities.

How can the degree of financial market integration be measured in practice?

The various measures of financial integration can be grouped into three broad categories: de jure, de facto, hybrid indicators and a combination of the former two. (Quinn et al, 2011). ${ }^{1}$ De jure indices of financial globalization do not reflect the extent to which actual capital flows evolve in response to legal restrictions, either because of a lack of enforcement, or because controls in one area may induce a response in other asset flows. De facto indicators are: quantity-based, price-based, and hybrid measures where quantity-based integrate a country's aggregate assets plus liabilities relative to its gross domestic product, and includes the categories of portfolio equity, FDI, debt, and financial derivatives, as well as assets and liabilities for each (Lane 
and Milesi-Ferretti's (2006, 2007)). The United Nations Commission on Trade and Development (UNCTAD) provides two other quantity measures, which are inward FDI flow and stock. Because of different methodologies, proxy of capital account openness, country sample, and time coverage it is not possible to compare the results of different studies.

Lane and Milesi- Ferretti $(2003 ; 2007)$ assessed the level of financial integration. These indexes measure countries' stock of external assets and liabilities from the flow data computed by the International Monetary Fund (IMF) also known as the International Investment Position (IIP). The two measures are IFIGDP (includes all five categories of the IMF's IIP: portfolio investments, foreign direct investments (FDI), other investments, financial derivatives and reserve assets, all as a share of GDP) and GEQY (the equity components of IIP: the portfolio investment in equity as well as FDI).

Baele et al. (2004) consider three broad categories of financial integration measures: price-based measures (which capture discrepancies in prices or returns on assets caused by the geographic origin of the assets; it is as yield-based and country effects); news-based measures (which measure the information effects from other frictions or barriers) and quantity-based measures (which quantify the effects of friction faced by the demand for and supply of investment opportunities). They propose a number of measures to quantify the state and evolution of financial integration (the money, corporate bond, government bond, credit and equity markets) in the euro area (and its member countries). In the case of perfect capital mobility the law of one price should appear - euro area assets with the same risk that generate identical cash flows should trade at the same price. Given this definition, financial market integration can be measured by comparing the returns of assets that are issued in different countries and generate identical cash flows. Identifying such assets is of course a difficult task. In a situation where identical assets command different returns we can say that financial markets are not fully integrated because legal barriers prevent capital from freely flowing between countries. Barriers may reflect capital controls, tax codes, accounting and auditing differences, different bankruptcy law, different quality of judicial enforcement, etc. However, some caution is warranted. Adam et al. (2002) proposed the cross-sectional dispersion in bond yields as a measure of the degree of integration.

Gehringer (2013) investigated the de facto and de jure measures of financial liberalization and examined their influence on economic growth. She has researched the financial globalization in Europe dividing Europe into three groups: Eastern Europe, PIIGS and core Eurozone countries. Financial liberalization appeared to be beneficial - although to a different degree - in all three groups of countries. Eastern European countries experienced the clearest and the strongest positive impact on the direct and indirect growth channels. For the core of the euro area no significantly positive effect could be found. Medve-Bálint (2014) highlights the importance of EU 
membership for the liberalization of investment regime in the CEE region and after enlargement the CEE countries have improved the locational advantages through incentive schemes offered to foreign investors. Most FDI comes mainly from the old EU member states so the FDI in CEE has enhanced the global competitiveness of western European firms.

Pungulescu (2013) compared the financial market integration (credit and bond market indicators, stock market indicators, indicators based on household and firm decisions and indicators of institutional differences) in EU15 and East-European countries and she found relatively slow convergence with achievements in money markets and clear positive developments for government bonds. Stock market integration has started, but is generally weak. The CEE countries are very heterogenous regarding the level of financial integration where the best performers are the Czech Republic, Hungary, Poland and Estonia. Babetski et al. (2007) researched the level of financial integration between eurozone countries and four new EU member states (the Czech Republic, Hungary, Poland and Slovakia) using beta and sigma convergence. They found evidence of stock market integration on the national and sectoral level between the observed countries and euro area.

Kucerova Z. (2009) starts with the thesis that "full financial market integration is one of the inevitable conditions for successful introduction of common currency, so the currency could circulate within the monetary union without any barriers. This allows more efficient allocation of the capital." She focused on the analysis of the international investment positions of eight new EU member countries and found significant linkage between EU8 foreign assets and liabilities and EU8 foreign trade, the growing foreign trade of the EU8 countries contributes to an increase in the level of foreign assets and liabilities, and thus to the fostering of European foreign financial linkages, which is seen as vital for the further integration of financial markets.

König and Ohr (2013) created an index for the measurement of European economic integration which consists of four components one of them being EU single market. In the assessment of the EU single market, financial integration is measured as a level of intra-EU FDI inward and outward stock, and they advise that they cannot include the data about portfolio investments and other intra-European cross-border holdings because of the limited data availability. They also constrain their investigation to just the EU15. Globan (2014) found an increase in the explanatory power of interest rates for capital movements shortly before and after the accession of post-transition economies to the EU, but the recent financial crisis made capital flows less sensitive to interest rates because of increased risk aversion on international capital markets.

Chinn and Ito (2008) created the Chinn-Ito index (KAOPEN) - it is an index measuring a country's degree of capital account openness. The index is based on the binary dummy variables that codify the tabulation of restrictions on cross-border financial transactions reported in the IMF's Annual Report on Exchange Arrangements and Exchange Restrictions (AREAER). KAOPEN is the first principal compo- 
nent of the original variables pertaining to regulatory controls over current or capital account transactions, the existence of multiple exchange rates, and the requirements of surrendering export proceeds (Chinn and Ito, 2008). Values are from -1.89 to 2.39. Ka-open is Chinn-Ito index normalized to range between zero and one. The highest value of KAOPEN and the value of ka-open closer to 1 characterize very (financially) open economies.

This review indicated the existence of a set of measures to assess the level of financial liberalization (integration). It would be too ambitious to attempt to cover all of them and we have focused on capital market integration where we will consolidate the economic and regulatory side of it.

\section{Measurement of Capital Mobility in the EU New Member States}

In this part we are focused on the analysis of capital market integration. With reference to the literature review, we will show the following indicators: Chin-Ito index (kaopen); international investment position (IIP); FDI intensity, bond yields and share of foreign assets and liabilities in GDP. Our research is focused on the new EU member states: Bulgaria, Croatia, the Czech Republic, Cyprus, Estonia, Hungary, Latvia, Lithuania, Malta, Poland, Slovakia, Slovenia, and Romania covering the period from 2004 to 2013. We will compare the different indicators of capital market integration.

Figure 1: KAOPEN for the EU new member indexes

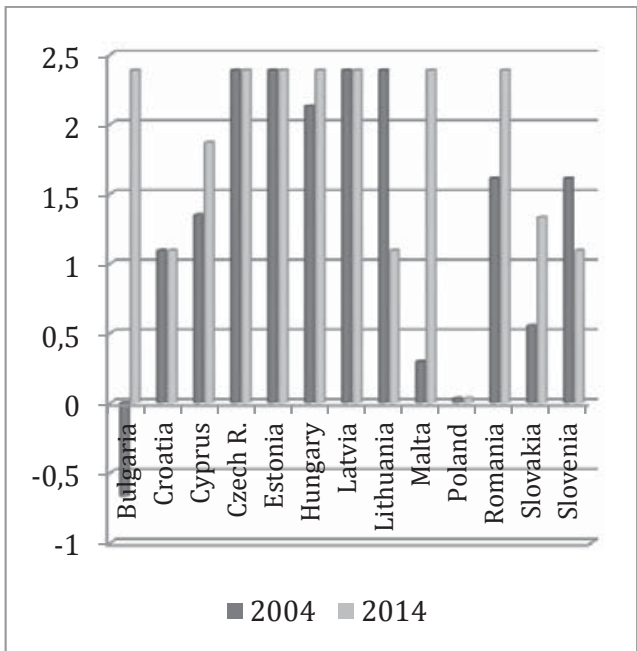

Figure 2: KAOPEN for the EU new member states-scores

Source: Chinn, M., \& Ito, H. (2008). A New Measure of Financial Openness, Journal of Comparative Policy Analysis, 10(3): 309-322, http://web.pdx.edu/ ito/Chinn-Ito_website.htm. 
From Figures 1 and 2 we can observe that the Czech Republic, Estonia, Hungary and Latvia have the highest level of financial integration in 2004 and in 2013, while Bulgaria, Romania and Malta have increased the level of openness (and in 2013 they are also very open). Lower levels of openness are seen in Croatia, Cyprus, Slovakia and Slovenia while Poland has the lowest level.

Figure 3: FDI intensity, market integration (\% of GDP)

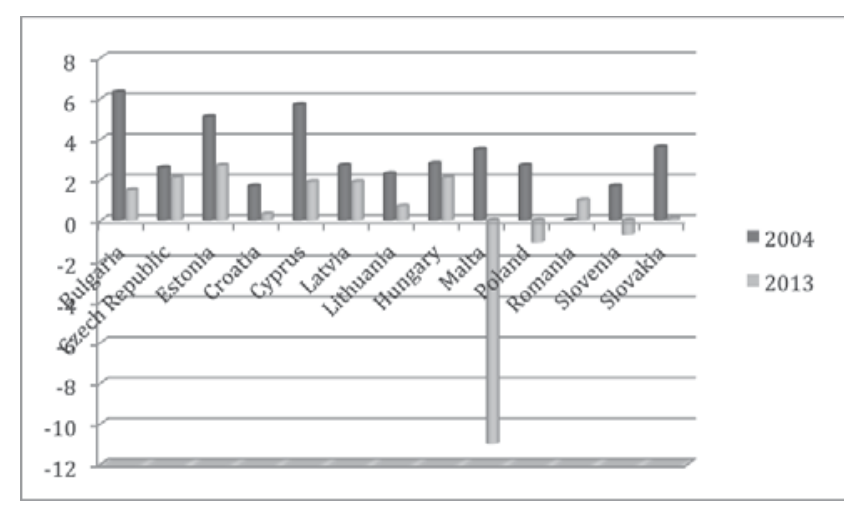

FDI flows intensity= average of inward and outward Foreign Direct Investment (FDI) flows divided by gross domestic product (GDP). The index measures the intensity of investment integration within the international economy.

Source: Eurostat.

Figure 4: Net international investment position \% GDP

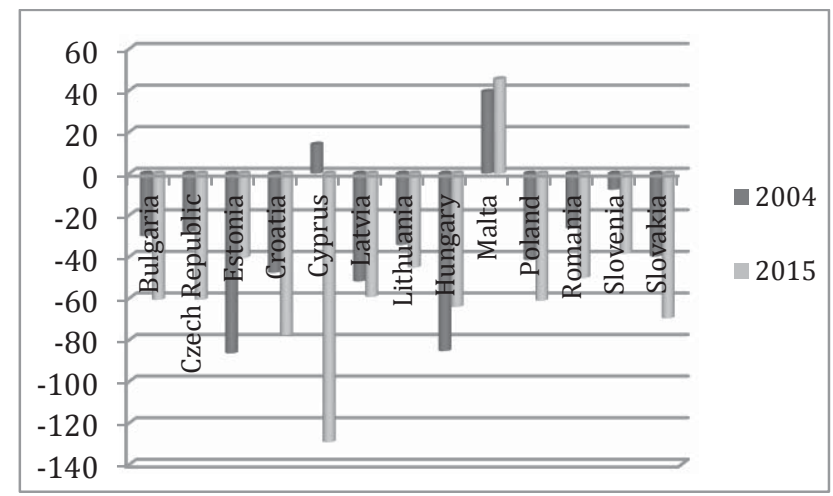

Source: Eurostat.

International investment position (IIP) statistics record the financial assets and liabilities position of a country vis-à-vis the rest of the world. It allows for a stock- 
flow analysis of the external position of the country. The net international investment position is calculated as IIP assets minus liabilities. It allows for a stock-flow analysis of external positions. The indicative threshold is $-35 \%$.

The positive value indicates the country is net creditor and the negative means the country is net debtor. From Figure 4 it is clear that all the countries, except Malta, are debtors where Hungary, Croatia and Cyprus are leading. Estonia, Latvia, Lithuania and Slovenia are also debtors but with a lower level of IIP. Majority of debtor countries saw an increase in the negative IIP in 2015 in comparison with 2004. All EU new member states, except Malta, have IIP higher than threshold. This supports the fact that entry into the EU has enabled greater access of foreign capital, and these countries based their development on borrowing and foreign investment.

Figure 5: Bond yields - difference

Germany bond yields in 2004 and in 2015 (in pp)
Figure 6: Market capitalization in towards 2004 and in 2015 (in $\%$ of GDP)

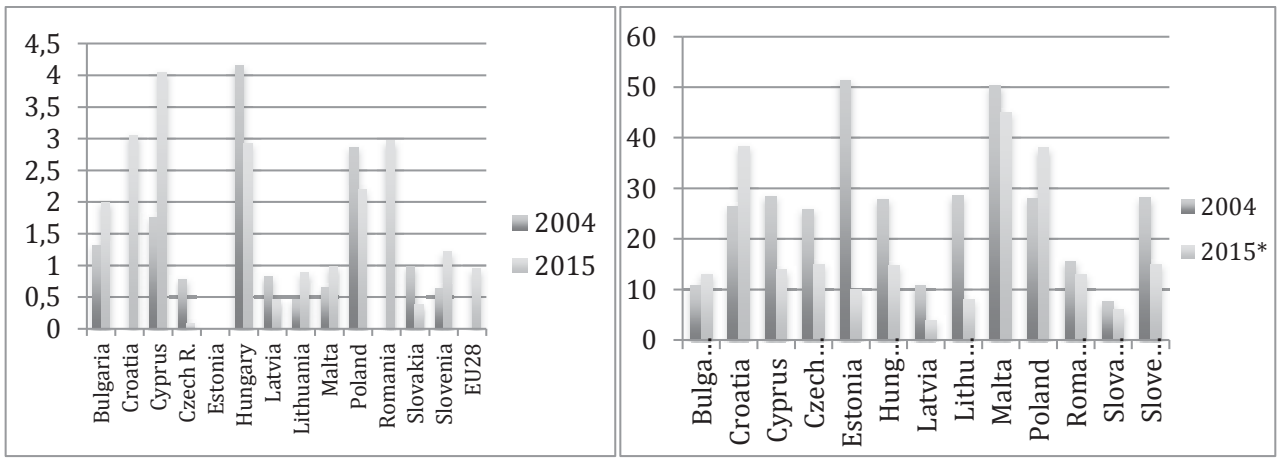

Long term government bond yields refer to central government bond yields on the secondary market, gross of tax, with a residual maturity of around 10 years. The bond or the bonds of the basket have to be replaced regularly to avoid any maturity drift. This definition is used in the convergence criteria of the Economic and Monetary Union for long-term interest rates.

* Some data for market capitalization are for 2014 or 2013 due to noavailability of data for 2015.

Source: European Central Bank (ECB), Eurostat; World Bank Development Indicators, http://data.worldbank.org/ indicator/CM.MKT.LCAP.GD.ZS.

The highest differences of bond yields towards the German bonds are seen in Cyprus, Hungary, Croatia and Romania (abut 3 percentage points). The lowest difference is in the Czech Republic and Slovakia. In all countries, this difference increased during the global financial crisis years and now it is in trend of declining and stabilizing. The increase of difference in interest rates represents the worsening of borrowing conditions in international financial markets (largely a consequence of the global financial crisis). 
Market capitalization (also known as market value) is the share price times the number of shares outstanding. Listed domestic companies are the domestically incorporated companies listed on the country's stock exchanges at the end of the year. Listed companies do not include investment companies, mutual funds, or other collective investment vehicles. It is an indicator of the size of the financial sector given by the market value of listed shares divided by GDP and it is frequently used as an indicator of market development.

The picture of the capitalization of the stock market is very mixed - some countries have a marked increase (three countries: Bulgaria, Croatia and Poland) while in the majority of countries this ratio has decreased. Malta, Croatia and Poland have the highest value in 2013 while Cyprus, Estonia, Latvia, Lithuania and Slovakia have a ratio of below $10 \%$. This trend indicates the problem of stock market development and dynamics in the post-crisis period. Stock market capitalisation for the EU is $52.8 \%$ of GDP in 2015, which is lower than in the USA (139.7\%) and Switzerland (228\%). The new member states are significantly lagging behind the EU average and the developed EU member states.

\section{Research}

The quantitative analysis is focused on identifying the main macroeconomic variables that influence capital mobility. As there are variety of variables which measures the capital mobility we will provide analysis by choosing two dependent variables: ka-open and FDI inward stock. Ka-open is important as it measures a country's degree of capital account openness and FDI inward stock's relevance is in the fact that majority of capital flows in EU new member states were realized through foreign direct investments. We have made analysis for the group of new EU member states.

The first model is:

$$
(\text { ka-open })_{\mathrm{i}, \mathrm{t}}=\alpha+\beta(\text { GDPpc })_{\mathrm{i}, \mathrm{t}}+\gamma_{1} \mathrm{X}_{1} \ldots \mathrm{n}_{\mathrm{i}, \mathrm{t}}+\varepsilon_{\mathrm{it}}
$$

Where ka-open is a measurement of capital account openness; and $\mathrm{X}_{1} \ldots \mathrm{n}_{\mathrm{i}, \mathrm{t}}$ are a set of independent variables: intra-EU trade (the share of export and import with other EU member states in total export and import); inflation (annual increase of consumer prices, HICP), FDI inward stocks; GDP per capita (in PPP); budget deficit (share of GDP), level of public debt (share in GDP), interest rates (in \%), GFCF (gross fixed capital formation) and market capitalization (in \% of GDP).

The second model is:

$$
(\text { FDI inward stock })_{\mathrm{i}, \mathrm{t}}=\alpha+\beta(\mathrm{GDPpc})_{\mathrm{i}, \mathrm{t}}+\gamma_{1} \mathrm{X}_{1} \ldots \mathrm{n}_{\mathrm{i}, \mathrm{t}}+\varepsilon_{\mathrm{it}}
$$


Where FDI inward stock indicate the amount of attracted FDI (in og forms); and $\mathrm{X}_{1} \ldots \mathrm{n}_{\mathrm{i}, \mathrm{t}}$ are a set of independent variables: GDP per capita (in PPP); intra-EU trade (the share of export and import with other EU member states in total export and import); inflation (annual increase of consumer prices, HICP), ka-open; budget deficit (share of GDP), level of public debt (share in GDP), GFCF (gross fixed capital formation), interest rates (in \%) and market capitalization (in \% of GDP).

The data (on the annual level) are from the Eurostat database and World Bank database and cover the period from 2000 to 2014. Considering that the sample has a cross-sectional dimension, represented by countries $(\mathrm{i}=1 ;::: ; \mathrm{N})$ and a longitudinal dimension, represented by a time series ( $\mathrm{t}=1 ;::: ; \mathrm{T}$ periods) panel data method is used. The sample comprises unbalanced panel data, that is, there are some periods missing from some units in the population of interest. Panel data analysis can be static (fixed and random effects) and dynamic (Wooldrige, 2002, Hsiao, 2003 and Verbeek, 2008).The random effects and fixed effects estimation methods deal with the problem of non-observed heterogeneity. Fixed effects models capture country-specific effects with $\alpha_{i}$, that do not change over time, and random effects incorporates heterogeneity among the countries by including a specific non-observable effect $\left(\varepsilon_{\mathrm{it}}\right)$ in the error term. Although these are the estimation methods most commonly employed with panel data, their estimates are consistent only if the condition of strict exogeneity of regressors applies which will be verified by methodology proposed by Wooldridge (2002). The Hausman test indicates that fixed effects models are more suitable than random effects.

We have provided the static panel data analysis where the corrected models (for heteroskedasticity and/or autocorrelation) are presented (vce cluster robust models).

We expect the positive influence of variables: GDP p.c., intra-EU trade, stock market capitalization ratio, and negative impact of inflation, public debt and budget deficit on the level of capital mobility in the EU new member states. The variables GDP p.c. and FDI inward stock are in log forms while others are in percentage (annual increase or share in GDP).

We have made 5 models for the first (Table 1) and 5 models for the second relations (Table 2) with different combination of variables (Table 1). The first model indicates the variables GDP p.c. and intra-EU trade have positive and significant impact on the capital account openness where the first variable has a stronger influence. The second model found that FDI inward stock has positive impact on ka-open that is according to the economic theory. Public debt and budget deficit are not significant variables that have an influence on capital openness (models 3 and 4) indicating that fiscal imbalances do not impact the capital movement. Also, inflation, interest rates and market capitalization are not significat deteminants od capital account opennes. In the model 5 GFCF is significant variable but with negative sign it means more investment in economy the lower opennes of capital account.. Considering the fact that the majority of capital comes into the EU new member states from the rest of the 
EU in the form of foreign direct investment the positive impact of the variable FDI inward stock was expected but we also expected to show greater influence.

Table 1: Panel data analysis - fixed effects estimation (kaopen= dependent variable)

\begin{tabular}{|c|c|c|c|c|c|}
\hline & Model 1 & Model 2 & Model 3 & Model 4 & Model 5 \\
\hline $\log \mathrm{GDPpc}$ & $\begin{array}{c}0.6185563 \\
(0.2259041)^{*}\end{array}$ & $\begin{array}{c}0.0194358 \\
(0.2685294)\end{array}$ & $\begin{array}{c}0.793327 \\
(0.1847363)^{* * * *}\end{array}$ & $\begin{array}{c}0.8007069 \\
(0.1586857)^{* * * *}\end{array}$ & $\begin{array}{c}0.9004203 \\
(0.1736282)^{* * * *}\end{array}$ \\
\hline Intratrade & $\begin{array}{c}0.0302881 \\
(0.0106264)^{*}\end{array}$ & $\begin{array}{c}0.0309807 \\
(0.0073243)^{* * *}\end{array}$ & $\begin{array}{c}0.030556 \\
(0.0118838)^{*}\end{array}$ & $\begin{array}{c}0.027097 \\
(0.0142169)\end{array}$ & $\begin{array}{c}0.0315095 \\
(0.0122377)^{*}\end{array}$ \\
\hline \multicolumn{6}{|l|}{$\mathrm{CA}$} \\
\hline Inflation & $\begin{array}{c}-0.0088031 \\
(0.0047678)\end{array}$ & $\begin{array}{l}-0.0023669 \\
(0.0040793)\end{array}$ & $\begin{array}{c}-0.0065601 \\
(0.0065508)\end{array}$ & $\begin{array}{l}-0.0093971 \\
(0.0047036)\end{array}$ & $\begin{array}{l}-0.0028774 \\
(0.0055955)\end{array}$ \\
\hline Budget deficit & & & $\begin{array}{c}0.005418 \\
(0.0114347)\end{array}$ & & \\
\hline Public debt & & & & $\begin{array}{c}-0.002986 \\
(0.0026286) \\
\end{array}$ & \\
\hline $\log$ FDIinwstock & & $\begin{array}{c}0.2424301 \\
(0.052096)^{* * *}\end{array}$ & & & \\
\hline $\log \mathrm{GFCF}$ & & & & & $\begin{array}{c}-0.0875331 \\
(0.012607)^{* * *} \\
\end{array}$ \\
\hline Market capital. & & $\begin{array}{c}0.0018168 \\
(0.0011946) \\
\end{array}$ & & & \\
\hline Interest rates & $\begin{array}{c}-0.008529 \\
(0.0096305)\end{array}$ & $\begin{array}{l}-0.0103562 \\
(0.0054084)\end{array}$ & $\begin{array}{l}-0.0022628 \\
(0.0080326)\end{array}$ & $\begin{array}{l}-0.0041533 \\
(0.0097969)\end{array}$ & $\begin{array}{l}-0.0030409 \\
(0.0066659)\end{array}$ \\
\hline $\mathrm{R}$ square & 0.3022 & 0.5618 & 0.3646 & 0.3822 & 0.5315 \\
\hline No. of obs. & 144 & 127 & 141 & 141 & 141 \\
\hline
\end{tabular}

All models include constant variable. Standard errors are in parenthesis. ***P statistically significant at $1 \%$. **P statistically significant at $5 \%$. $* \mathrm{P}$ statistically significant at $10 \%$.

Source: author's calculation.

Considering the determinants of FDI inward stocks (Table 2) we found the following results: GDP per capita is the most important variable with positive and strong impact; intra-regional trade is significant just in Model 2; ka-open is significant variable with positive impact on FDI inward stock. Inflation has negative impact as well as GFCF (higher investment reduce the need for foreing capital); while fiscal variables, market capitalization and interest rates are not significant variables.

The strongest impact comes from GDP p.c. that indicates the level of economic development as a main driver of capital mobility. A further interesting finding is that interest rates do not have significant impact on the capital account openness. Intra-EU trade has a positive but weak influence on the capital mobility while we did not find any significant influence of fiscal variables. 
Table 2: Panel data analysis - fixed effects estimation (FDIinwardstock= dependent variable)

\begin{tabular}{|c|c|c|c|c|c|}
\hline & Model 1 & Model 2 & Model 3 & Model 4 & Model 5 \\
\hline $\log \mathrm{GDPpc}$ & $\begin{array}{c}3.519975 \\
(0.3622244) * * *\end{array}$ & $\begin{array}{c}2.549132 \\
(0.3397143)^{* * *}\end{array}$ & $\begin{array}{c}3.733008 \\
(0.4077372)^{* * *}\end{array}$ & $\begin{array}{c}3.711969 \\
(0.4359746)^{* * *}\end{array}$ & $\begin{array}{c}3.901169 \\
(0.3871644)^{* * * *}\end{array}$ \\
\hline Intratrade & $\begin{array}{l}-0.0076889 \\
(0.0191172) \\
\end{array}$ & $\begin{array}{c}-0.0419218 \\
(0.0124087)^{*}\end{array}$ & $\begin{array}{c}-0.008568 \\
(0.0230746)\end{array}$ & $\begin{array}{c}-0.0030956 \\
(0.021191) \\
\end{array}$ & $\begin{array}{l}-0.0080898 \\
(0.0230058) \\
\end{array}$ \\
\hline kaopen & & $\begin{array}{c}1.307708 \\
(0.196183)^{* * *}\end{array}$ & & & \\
\hline Inflation & $\begin{array}{c}-0.0364729 \\
(0.008372)^{* * *}\end{array}$ & $\begin{array}{l}-0.0204412 \\
(0.0093686)\end{array}$ & $\begin{array}{c}-0.0362252 \\
(0.0113961)^{*}\end{array}$ & $\begin{array}{c}-0.0310458 \\
(0.0112202)^{* *}\end{array}$ & $\begin{array}{c}-0.0319949 \\
(0.0092348)^{* *}\end{array}$ \\
\hline Budget deficit & & & $\begin{array}{c}0.0065307 \\
(0.0197204)\end{array}$ & & \\
\hline Public debt & & & & $\begin{array}{c}0.0023983 \\
(0.0051138) \\
\end{array}$ & \\
\hline $\log \mathrm{GFCF}$ & & & & & $\begin{array}{c}-0.1280309 \\
(0.0111911)^{* * *}\end{array}$ \\
\hline Market capital. & & $\begin{array}{l}-0.0018904 \\
(0.0014739) \\
\end{array}$ & & & \\
\hline Interest rates & $\begin{array}{c}0.0163351 \\
(0.0186436) \\
\end{array}$ & $\begin{array}{l}0.0221125 \\
(0.01045) \\
\end{array}$ & $\begin{array}{c}0.0214698 \\
(0.0125009) \\
\end{array}$ & $\begin{array}{l}0.0135584 \\
(0.019534) \\
\end{array}$ & $\begin{array}{c}0.02204 \\
(0.0147063) \\
\end{array}$ \\
\hline $\mathrm{R}$ square & 0.6068 & 0.7273 & 0.5984 & 0.5991 & 0.6447 \\
\hline No. of obs. & 130 & 127 & 127 & 127 & 127 \\
\hline
\end{tabular}

All models include constant variable. Standard errors are in parenthesis. ***P statistically significant at $1 \%$. **P statistically significant at $5 \%$. $* \mathrm{P}$ statistically significant at $10 \%$.

Source: author's calculation.

\section{Conclusion}

In approaching to capital market integration we faced with different way how to measure it. Regards it relates to contemporary issue EU wanted to improve and achieve we contributed with the analysis focused on the EU new member states. Measuring capital mobility is very complex and requires the analysis of several indicators. We have compared capital market integration in the period before the accession to the EU with the results in 2015.

The results indicate a mixed picture of capital market integration regarding the observed indicators. The most integrated countries are Malta, Poland and Croatia (stock market capitalization ratio), the Czech Republic and Slovakia (interest rate spreads); Hungary, Croatia and Cyprus (IIP); the Czech Republic, Estonia, Hungary and Latvia (KAOPEN); Estonia, the Czech Republic and Hungary (FDI intensity). The countries that are in the top regarding two or more indicators are: Hungary, the Czech Republic, Croatia and Estonia. The observed countries show a very heteroge- 
neous level of capital market integration that is in accordance with the conclusions of Pungulescu (2013) and their markets are just partially integrated.

It is interesting to compare these results with their trade relations (integration) intra-EU trade. Among these four countries only Hungary and the Czech Republic have a very high value of trade with EU member states (above 70\%). Croatia is oriented towards the EU but also to its neighboring countries (South and East Europe), and Estonia, apart from the EU, trades with Eastern partners. So, the financial integration is only partly explained by intra-regional trade (and move in the same direction but not in the same intensity), and a huge part is independent of exports and imports of goods and services. Econometric analysis emphasized that the level of development (measured with GDP p.c.) is the main determinant for capital openness (mobility) and FDI inward stock. Other variables that also have a positive influence are intra-EU trade, FDI inward stock (for the ka-open model), while inflation and gross fixed capital formation have a negative impact on capital mobility. Another interesting finding is that fiscal variables (budget deficit and public debt), market capitalization ratio and interest rates do not have a significant impact on capital openness and FDI inward stock. Globan (2014) also found that capital flows are less sensitive to interest rates because of increased risk aversion on international capital markets.

The differences among CEE countries in the analyzed indicators of capital market integration indicate that there is room for improvement in all countries (in particular areas) which would enable more favorable access to capital for companies, the state and citizens in CEE. Higher levels of integration could stimulate, so anticipated, higher rates of economic growth.

\section{REFERENCES}

Adam, K., Jappelli, T., Menichini, A., Padula, M. and Pagano, M. (2002). Analyse, compare and apply alternative indicators and monitoring methodologies to measure the evolution of capital market integration in the European Union. CSEF. European Commission, 1-95.

Babetskii, I., Komarek, L. Komarkova, Z. (2007). Financial integration of stock markets among new EU member states and the euro area. Finance a Uver-Czech Journal of Economics and Finance, 57 (7-8), 341-362

Baele, L., Ferrando, A., Hördahl, P., Krylova E. and Monnet, C. (2004). Measuring financial integration in the euro area. European Central Bank, Occasional Paper, No.14.

Chinn, M., and Ito, H. (2008). A New Measure of Financial Openness. Journal of Comparative Policy Analysis, 10 (3), 309-322.

European Commission (2015a). Action Plan on Building a Capital Markets Union. Retrived October 28, 2015, from: http://ec.europa.eu/finance/capital-markets-union/docs/building-cmu-actionplan_en.pdf .

European Commission (2015b). Intra-EU trade in goods - recent trends. Retrived Ocotber 25, 2015, from: http://ec.europa.eu/eurostat/statistics-explained/index.php/Intra-EU_trade_in_ goods_-_recent_trends. 
Eurostat, Economy and finance. Retrived October 30, 2015, from http://ec.europa.eu/eurostat.

Gehringer, A. (2013). Growth, productivity and capital accumulation: The effects of financial liberalization in the case of European integration, International Review Of Economics \& Finance, 25, 291-309.

Grossman E. and Leblond, P. (2011). European Financial Integration: Finally the Great Leap Forward? Journal of Common Market Studies, 49 (2): 413-435.

Guha, P., Daga, S., Gulati, R., Bhupal, G. and Oak, H. (2004). International Financial Markets Integration or Segmentation: A Case Study of Equity Markets. EconWPA Working Paper, No. 0412013

Hsiao, C. (2003). Analysis of panel data, Cambridge; Cambridge University Press, 2nd edition. UK.

Globan, T. (2014). Testing the 'trilemma' in post-transition Europe - a new empirical measure of capital mobility. Post-Communist Economies, 26 (4), 459-476.

Kalemli-Ozcan, S. and Manganelli, S. (2008). Financial Integration and Risk Sharing: The Role of the Monetary Union in 5th European Central Banking Conference on The Euro at Ten: Lessons and Challenges, Frankfurt: ECB.

König, J and Ohr, R. (2013). Different Efforts in European Economic Integration: Implications of the EU Index. Journal of Common Market Studies, 51 (6), 1074-1090.

Kucerova, Z. (2009). Measuring Financial Integration in Central Europe Through International Investment Positions. Eastern European Economics, 47 (4) 25-41.

Lane, P. R., and Milesi-Ferretti, G. M. (2007). The external wealth of nations mark II: Revised and extended estimates of foreign assets and liabilities, 1970-2004. Journal of International Economics, 73(2), 223-50.

Lane, P. R., and Milesi-Ferretti, G. M. (2003). International Financial Integration. IMF Staff Papers, 50 (Special Issue), 82-113.

Medve-Bálint, G. (2014). The Role of the EU in Shaping FDI Flows to East Central Europe. Journal of Common Market Studies, 52 (1), 35-51.

OECD (2015). FDI Regulatory Restrictiveness Index. Retrived Novemver 18, 2015, from: http://stats. oecd.org/Index.aspx?datasetcode=FDIINDEX\#

Oxelheim, L. (1990). International Financial Integration. Springer Verlag: Berlin.

Pungulescu C. (2013). Measuring financial market integration in the European Union: EU15 vs. New Member States. Emerging Markets Review, 17, 106-124.

Quinn, D., Schindler, M. and Toyoda, A.M. (2011). Assessing Measures of Financial Openness and Integration. IMF Economic Review, 3, 488-522. doi:10.1057/imfer.2011.18

Stavárek, D., Repková, I. and Gajdošová, K. (2012). Theory of financial integration and achievements in the European Union. In Matoušek, R., Stavárek, D. (eds.) Financial Integration in the European Union. Routledge Studies in European Economy. London: Routledge.

Verbeek, M. (2008). A guide to modern econometrics. $3^{\text {rd }}$ Edition. John Wiley\&Sons, Ltd: New York.

Wooldridge, J. M. (2002). Econometric Analysis of Cross Section and Panel Data. MIT Press:.Cambridge.

World Bank Development Indicators. Retrived November 28, from: http://databank.worldbank.org/ data/views/reports/tableview.aspx.

\section{NOTES}

${ }^{1}$ Some of de jure indicators are limited due to their binary nature: countries are closed or open (they cannot measure the situation of countries that are partly open, those that are substantially but not fully open). 